\title{
SOME FLIES OF THE FAMILY SYRPHIDAE, MESOGRAMMA
}

\author{
By Frank M. HULL \\ University of Mississippi
}

This paper describes some new species of Syrphidae from the Neotropical region, derived from various sources. Types are in the author's collection unless otherwise stated.

Mesogramma vitrea $n$. sp.

Male. Length $5 \mathrm{~mm}$. Head: face and front and antennæ light, pale yellow, the cheeks black, the vertex golden brown, becoming coppery just behind the ocelli. Occiput metallic brassy above, greyish white along the sides. Thorax: metallic brassy brown with a prominent median steel blue stripe on either side of which are two dark brown and two light brown stripes. Pleuræ shining metallic, with a small obscure yellow spot on the upper part of the sternopleuræ and the posterior margin of the mesopleuræ. Scutellum and humeri metallic brassy black. Abdomen: highly polished and shiny, first three segments wholly black, last two segments dark shining reddish brown. Hypopygium shining black. Pile of abdomen abundant, rather long, whitish upon the margins and lateral portions of all of the segments and blackish upon a central stripe down the middle of the abdomen which begins upon the posterior part of the second segment. Legs: chiefly shining black, the tips of the femora, the tips of the hind tibiæ and its base yellow. Hind basi-tarsi and the three terminal joints dark brownish black. Middle of the fore and mid-tibiæ with an obscure brownish band. Anterior tarsi darkened. Wings: pale brownish.

Holotype male. São Paulo, Juquia, J. Lane, Nov. 7.

Mesogramma picta Sch. variety melleoguttata $\mathrm{n}$. var.

Female. Length $6 \mathrm{~mm}$. Head: vertex violet, front shining metallic black, its narrow sides and the face pale yellow, 
cheeks black, occiput brassy brown above, becoming yellowish grey on the sides and below. Antennæ brownish, the ventral portion reddish orange. Arista brownish black, the antennal pile black. Thorax: with a broad median bluish grey shining vittæ, and lying outside of it, first a pair of dark brown vittæ, then a pair of somewhat yellowish vittæ, and bordering the continuous yellow side markings are a pair of wide brown vittæ. Pleuræ yellow on the posterior margin of the mesopleuræ and upper part of sternopleuræ. Scutellum metallic black, the margin pale yellow. Abdomen: black marked with light yellow, sides of the first segment and its narrow margin, a complete transverse stripe on the second segment that reaches the sides, its anterior corners narrowly, and traces of a median vittæ, all yellow. Third segment with a median yellow vittæ which does not quite reach the posterior margin and on either side of it two basal yellow spots. The outermost pair subrectangular, occupying the corners and narrowly confluent at the base with the submedial much larger spots which are twice as long as the more lateral ones. The submedial spot on inner surface is strongly indented and the black encroaches upon it, but only upon the basal half of its medial surface. Fourth segment with almost identically similar pattern. Fifth segment with large yellow spots on the basal corners and a pair of widely separated elongate, yellow spots broadly reaching the base of the segment with the posterior ends rounded and very slightly approximated. Legs: pale yellow, the hind tarsi, basal two-thirds of hind tibiæ and a wide black annulus apically upon the hind femora, black. Wings: pale grey, stigma pale brown.

Holotype female. Barro Colorado Island, Canal Zone, Aug. 25, 1937. Hull coll.

\section{Mesogramma elongata $n$. sp.}

Male. Length $13 \mathrm{~mm}$. Head: face and front yellow, the antennæ brownish yellow, third joint slightly darker dorsally, cheeks shining blackish, upper part of vertex brilliant violet, giving way to steel blue just behind the ocelli, area between the ocelli golden brown, lower part of the frontal triangle greyish pubescent. Occiput yellowish grey pubescent. Thorax: mesonotum with a broad bluish grey median stripe divided posteriorly by a narrow steel stripe the greater 
part of the mesonotum outside of the stripe golden brown. Between the golden brown and the lateral yellow margins is another metallic grey stripe. Humeri posterior two-thirds of the mesopleuræ and a spot on the upper part of the sternopleuræ pale yellow. Suctellum pale yellow, the disc broadly metallic brown. Abdomen: black marked with yellow, first segment about half black, the anterior part yellow including the lateral margin which is narrowly continuous with the lateral margin of the second segment. Second segment shining black, with an extensive transverse yellow band from margin to margin which is in width barely over one-fifth the length of the segment. Third segment broadly black upon the posterior part; about one third of the way from the end of the segment it sends forward a broad vittæ that rapidly expands into a large black spot, the anterior pointed end of which reaches the base of the segment. From the base of this median vittæ at its posterior point of origin, the black extends obliquely forward to the lateral margin of the segment and thence forward to occupy almost all of the lateral margin of the segment. At its lateral marginal apex it is confluent with a small oval black spot situated anteromedially, which small spot is narrowly separated from the large median subbasal spot. Fourth segment with similar pattern but the apex of the segment and lateral margins of the segment are extensively reddish brown and the somewhat smaller sublateral, subbasal black spots are more slender, more pointed and isolated. There is a fine narrow median reddish brown line bisecting the middle black vitta. Fifth segment with a pair of obtusely triangular submedial brown spots and lying just outside of these, touching the base are a pair of elongate brown vittate spots hollowed out on the inside, on the posterior two-thirds of their length. Legs: pale yellow, a brownish band subapically on the hind femur almost the whole of the basal half of the hind tibiæ and all of the hind tarsi, fore and middle tarsi brownish. Hind femora with considerable, rather long, black, bristly pile ventrally. Wings: hyaline, stigma dark brown.

Three males. Cotypes; Muzo, Department Boyaca, Columbia, altitude 900 meters, 1936. J. Bequært col. A specimen deposited in the Museum of Comparative Zoology. 
Salpingogaster pessulagyna $n$. sp.

Male. Length $13 \mathrm{~mm}$. Head: face, cheeks and front pale yellow, the latter with a brownish black longitudinal spot. Antennæ wholly light orange, its pile dark brown. Vertex blackish. Thorax: with a pair of prominent, narrowly separated, golden pollinose vittæ. On either side of these are an additional pair of somewhat less conspicuous golden vittæ; these outer vittæ are bordered by blackish brown. Humeri, most of the notopleuræ, post calli and a confluent spot anterior to them, the wide posterior margin of the scutellum, a transverse fascia upon its base all pale yellow. All of the pleuræ pale yellow except a narrow, oblique, brown band and a darker brown spot anterior to the halteres. Greater discal part of the scutellum and the metanotum brownish black. Abdomen: chiefly light reddish brown without black markings. The first segment pale yellow, its posterior margin with a brown fascia which, however, does not reach the base on either side. Fifth segment brownish yellow. Hypopygium pointed, last sternite with a pair of prominent black setate nodulose projections. Legs: light yellow, the middle and posterior femora narrowly yellowish brown subapically. Femoral setæ brown. Wings: pale brown with a well developed anterior brown margin reaching to the end of the wing, the costal cell paler.

Holotype: male. Barro Colorado, Aug. 28, 1938 (F. M. Hull, collector).

\section{Fazia hermosa n. sp.}

Male. Length $10 \mathrm{~mm}$. Head: face and lower part of occiput and the wide ocular margin of the front pale yellow. The pile abundant, long, erect and black. A broad black stripe running down the middle of the face enclosing the small but prominent tubercle. Front with a transverse, black spot above the widely separated antennæ, the spot continuing narrowly to the point of contact with the eyes. Epistoma standing out a little way beyond the base of the antennæ. Antennæ dark reddish brown, blackish along the dorsal third of the third joint. Mesonotum dull brownish black with a brassy cast, very feebly shining the humeri dark. There is a large, conspicuous, triangular, yellowish, noto- 
pleural spot that is confluent with a broad, post-marginal stripe of the mesopleuræ and an obscure spot on the upper spot of the sternopleuræ. Post calli and the scutellum light yellow, the latter with a diffuse, though conspicuous, black discal spot. Pile of thorax and pleuræ thick, erect and reddish brown, becoming longer and blacker on the scutellum. Abdomen: with nearly parallel sides, widest at the base of the fourth segment, where it is fully as wide as the widest part of the thorax. Abdomen nearly opaque black with five pairs of yellow spots, none of which, except the first pair on the first segment, reach the lateral margin. Spots on the first the segment. Third segment with more elongate spots, separated by less than the width of a spot. The spots of the fourth segment practically identical with the third; the spots rated by at least the length of a spot. The spots are roughly triangular, with rounded angles, and placed midway along the segment. Tihrd segment with more elongate spots, separated by less than the width of a soot. The spots of the fourth segment practically identical with the third; the spots of the fifth segment somewhat smaller, with sharply-pointed inner ends and more narrowly separated. Pile on the basal part of the abdomen reddish-brown, becoming almost yellow on the extreme corners, elsewhere black. Legs: chiefly black; base of the hind femora, their apices and the apices of the middle femora, front femora and the bases of their respective tibiæ dark brownish. Wings: with a strong brownish uniform tinge. Subapical cross vein elongate, the final section recurrent, the entire cross vein sigmoid.

Holotype: male. São Paulo, May 6-8, 1939 (J. Lane, collector). 

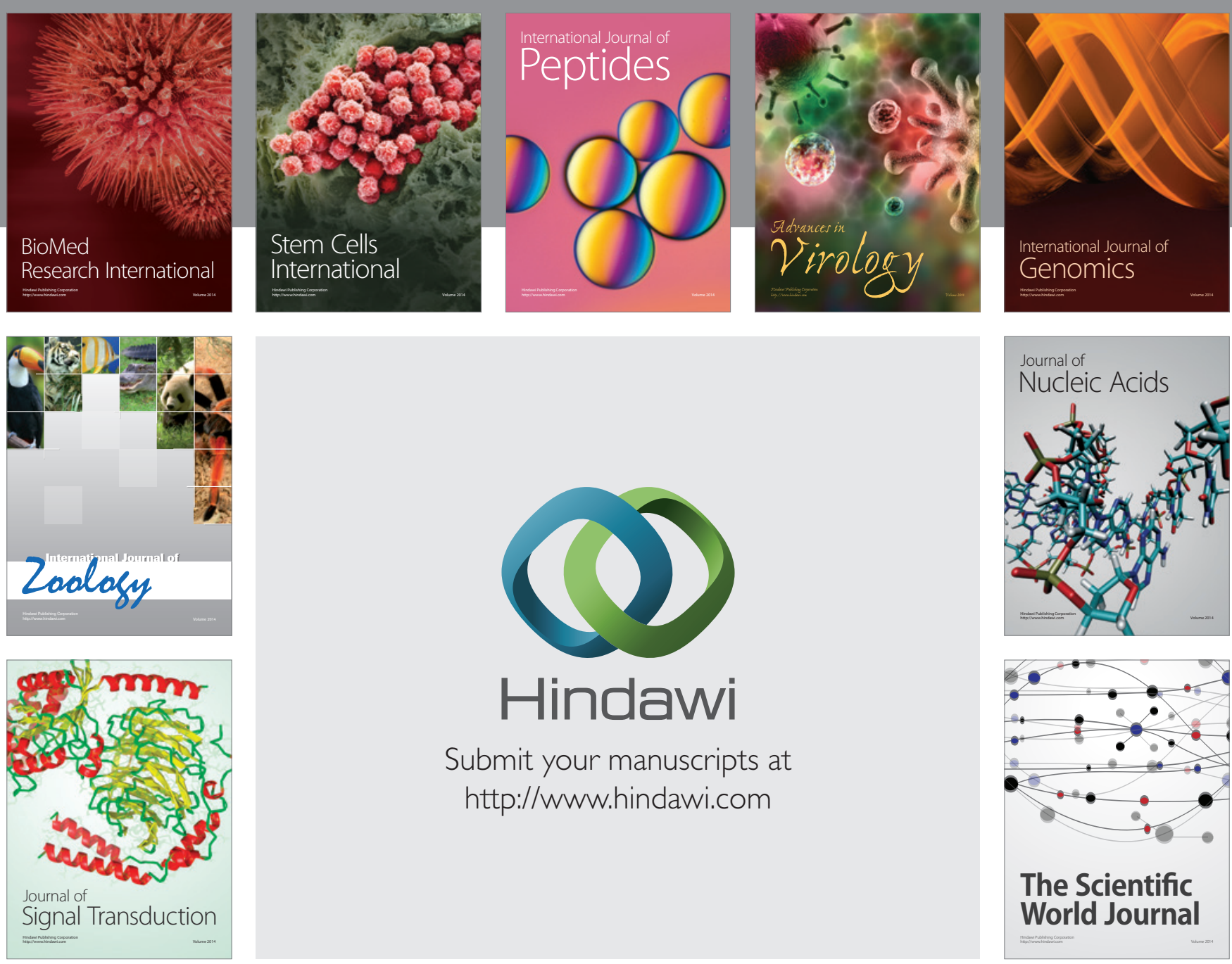

Submit your manuscripts at

http://www.hindawi.com
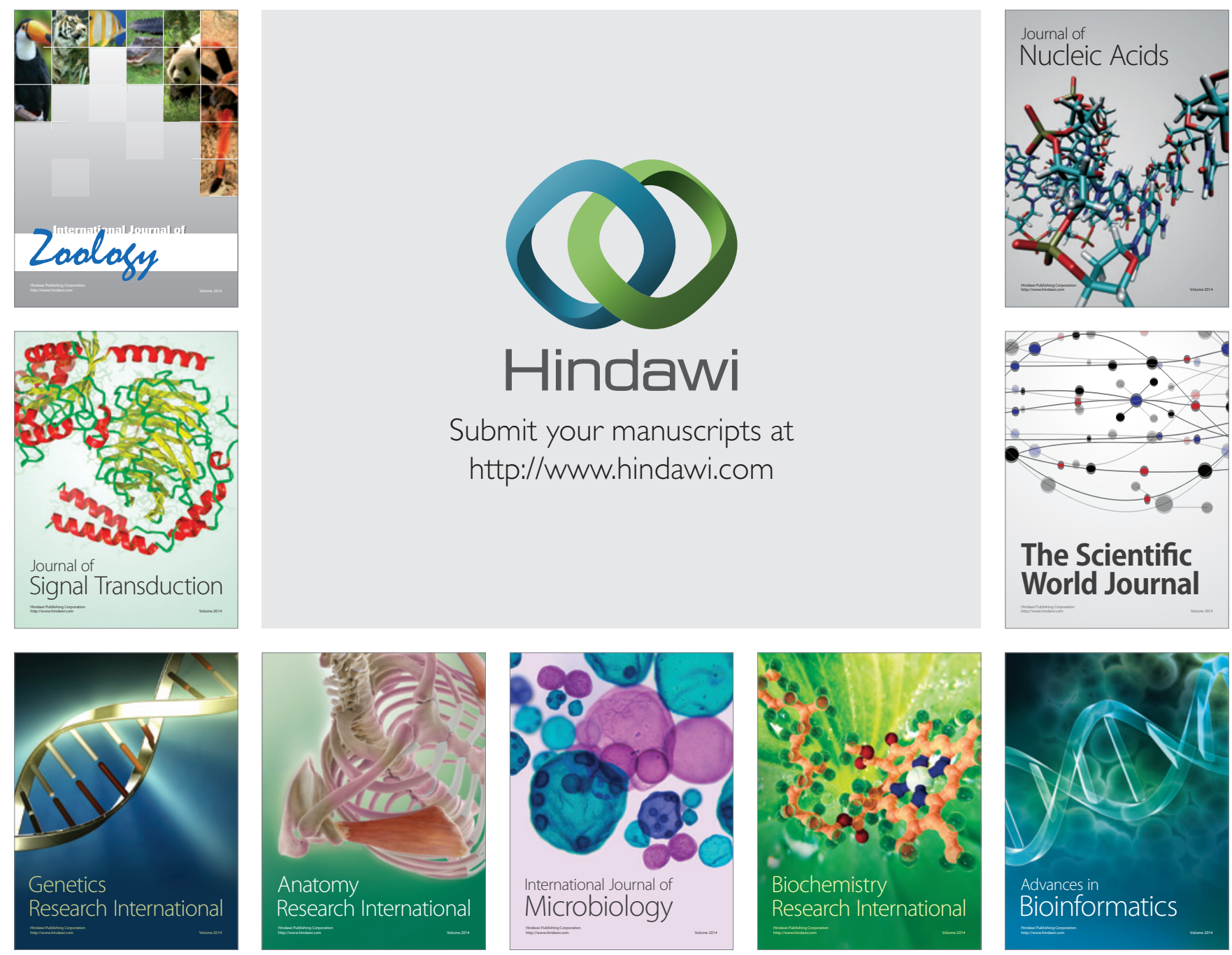

The Scientific World Journal
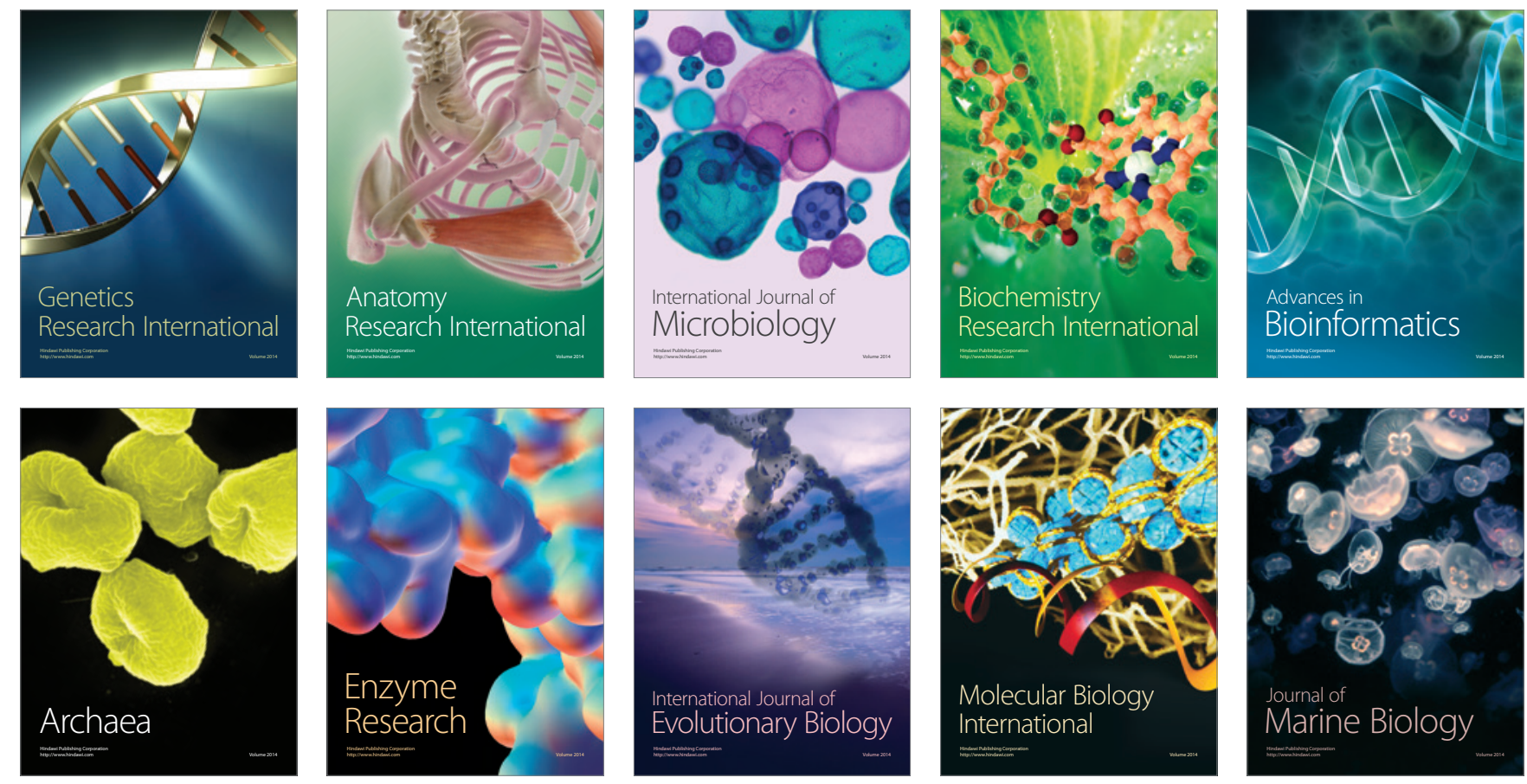